\title{
CORTICOSTEROIDS AND SECONDARY INFECTIONS: AN INSIGHT INTO CORONAVIRUS DISEASE-2019
}

\author{
BHARGAVI NEELA ${ }^{1 *}$, SHIRISHA JAKKULA ${ }^{1}$, MUJEEBUDDIN ${ }^{2}$, RAVINDRA PRATAP GAUR ${ }^{3}$
}

${ }^{1}$ Doctor of Pharmacy (Pharm.D), Intern at Clinosol Research Pvt. Limited, Ameerpet, Hyderabad, Telangana, India. ${ }^{2}$ Founder and CEO of Clinosol Research Pvt. Limited, Ameerpet, Hyderabad, Telangana, India. ${ }^{3}$ Associate Manager, Clinical Operations-Covance, Bengaluru, Karnataka, India. Email: neelabhargavi@gmail.com

Received: 25 October 2020, Revised and Accepted: 04 December 2020

\section{ABSTRACT}

Coronavirus disease 2019 (COVID-19), which is caused by novel coronavirus severe acute respiratory syndrome coronavirus 2 (SARS-CoV-2), emerged at Wuhan in China in December 2019 and has rapidly spread throughout the world. The droplets expelled during face-to-face exposure, mainly through talking, coughing, or sneezing, are the most common mode of transmission. So far, children have not been affected frequently without deaths. However, the course of this virus in the future is unknown. The diagnosis is mainly made through reverse transcription-polymerase chain reaction (RT-PCR) and serology testing. Treatment with dexamethasone at an early phase of developed acute respiratory distress syndrome (ARDS) caused by SARS-CoV-2 alters the pulmonary and systemic inflammatory response and decreases mortality. Corticosteroid therapy is associated with a sizable reduction in the duration of mechanical ventilation and hospital mortality. One of the major risk factor associated with corticosteroid therapy is associated with acquiring secondary infections. Pulmonary epithelial damage and inflammatory disease are the predisposing risk factors for pulmonary aspergillosis due to the release of danger molecular patterns during severe COVID-19. Galactomannan and culture testing of bronchoalveolar lavage fluid are the most sensitive diagnostic measures for aspergillosis in intensive care unit (ICU). Finally, the treatment of coronavirus associated pulmonary aspergillosis is complex. The only way one can prevent the spread of infection by following precautions such as frequent hand washing, wearing a mask in public places, social distancing, and by avoiding unnecessary gatherings.

Keywords: Coronavirus disease 2019, SARS-CoV-2, Acute respiratory distress syndrome, Dexamethasone, Pulmonary aspergillosis.

(C) 2021 The Authors. Published by Innovare Academic Sciences Pvt Ltd. This is an open access article under the CC BY license (http://creativecommons.org/ licenses/by/4.0/) DOI: http://dx.doi.org/10.22159/ajpcr.2021v14i1.40096. Journal homepage: https://innovareacademics.in/journals/index.php/ajpcr

\section{INTRODUCTION}

Coronavirus disease 2019 (COVID-19) is caused by a novel coronavirus which is named as severe acute respiratory syndrome coronavirus 2 (SARS-CoV-2) [1]. The virus originated in Wuhan City in Hubei Province in central China and it is currently spreading all across the globe causing a pandemic. The China Health Authority alerted the World Health Organization (WHO) to several cases of pneumonia of unknown origin on December 31, 2019 [2]. On January 30, 2020, the WHO declared the Chinese outbreak of COVID-19 to be a Public Health Emergency of International Concern and as a pandemic on March 11, 2020.

\section{ORIGIN AND HISTORY}

Since the virus appears with a crown-like projection on its surface, therefore the term Corona means a crown. It was first isolated in the late 1960s from patients suffering from the common cold [3]. Bees, palm civets, poultry, and animals are the main reservoirs of the virus. Until the outbreak of the SARS in 2002 in China [4], these viruses were thought to transmit infection only among animals. Middle Eastern countries later witnessed an outbreak of Middle East respiratory syndrome coronavirus [5]. Coronavirus is an enveloped (E-protein) single-stranded (positive-sense) RNA virus (+ssRNA) with club-shaped glycoprotein projections (S-protein). The spherical or pleomorphic form of the virus is $80-120 \mathrm{~nm}$ in size. The spikes are made of hemagglutininesterase [6].

SARS-CoV-2 is a member of the family Coronaviridae and it is subdivided into four genera (alpha, beta, gamma, and delta coronaviruses). SARS$\mathrm{CoV}-2$ belongs to betacoronavirus [7]. Based on the genome sequence studies of SARS-CoV-2, RaTG13 (a bat coronavirus), and SARS-CoV, they found that the virus is more related to RaTG13 with $96.2 \%$ overall genome sequence identity and also found that no evidence of recombination events detected in the genome of SARS-CoV-2.
Altogether, these findings suggest that bats might be the original host of this virus $[8,9]$.

In a recently published study, it has further established that sarbecovirus lineage is responsible for the pandemic of COVID-19 and concluded that the SARS-CoV-2 itself is not a recombinant of any sarbecoviruses detected to date and has been circulating unnoticed in bats for decades [10].

\section{EPIDEMIOLOGY}

Globally, 37601848 confirmed cases of COVID-19 with a death rate of $2.8 \%$ have been reported as of 13/10/2020. In India, a total of 7175880 cases has been confirmed with a death rate of $1.53 \%$ as of $13 / 10 / 2020$. The worst-hit countries due to COVID-19 are the USA, India, and Brazil. At the end of 2019, cases have been reported on all continents, except for Antarctica [11]. The reported cases underestimate the overall burden of COVID-19 since only a tiny proportion of acute infections are being diagnosed and documented. Seroprevalence findings within the United States and Europe have shown that the rate of exposure to SARS-CoV-2, expressed as seropositivity, exceeds the level of reported cases by 10-times or more after accounting for possible false positives or negatives [12].

COVID-19 has better outcome results in children than in adults with the exception of those hospitalized by a rare pediatric inflammatory system syndrome at intensive-care facilities [13]. Clinical presentations in pregnant women are generally moderate, with few cases of serious illness and fatal outcomes [14].

\section{MODE OF TRANSMISSION}

The possible origin of SARS-CoV-2 and the first mode of disease transmission are not yet identified [15]. The SARS-CoV-2 is alleged to have originated from an animal host (zoonotic origin) with the further 
human-to-human transmission; however, a study is needed to elucidate whether any intermediate hosts have facilitated the transmission of the virus to humans [16]. The Huanan South China Seafood Market sells live animals such as snakes, bats, poultry, and marmots. This may be the juncture where zoonotic (animal-to-human) transmission occurred. A study has elucidated that humans became infected with SARS-CoV-2 through pangolins, acting as an intermediate host [17].

The droplets expelled during face-to-face exposure in the course of talking, coughing, or sneezing is the most common mode of transmission. Prolonged exposure to the infected individuals (being for at least $15 \mathrm{~min}$ within 6 feet) and shorter exposures to symptomatic individuals (e.g., coughing) are associated with a higher risk of transmission, whereas short exposures to asymptomatic contacts are less likely to result in transmission [18]. Contact surface spread (touching a surface with the virus on it) is another possible mode of transmission and reinforces the potential for transmission through fomites (objects such as a doorknob, cutlery, or clothing) [19]. A recent study established that the virus, suspended it into a solution made to mimic human mucus, can stay as long as up to 28 days on the glass surfaces and plastic banknotes at $20^{\circ} \mathrm{C}$; however, at higher temperatures $\left(30^{\circ} \mathrm{C}\right.$ and $\left.40^{\circ} \mathrm{C}\right)$, the virus did not survive very long [20].

Aerosols (smaller droplets that remain suspended in the air) can also be transmitted, although it is unknown if this is a major source of infection in humans outside the laboratory setting. The risk of aerosol transmission, combined with droplet transmission, for example, during choir rehearsal and in restaurants, has been implied by some outbreak reports linked to indoor crowded spaces [21,22]. SARS-CoV-2 RNA has been found in blood and stool; however, fecal-oral transmission has not been reported [23]. SARS-CoV-2 transmission from people with infection but no symptoms, even those who developed symptoms later and were thus considered presymptomatic, has been well documented [24]. It is currently suspected that maternal COVID-19 is associated with a low vertical transmission risk. Maternal infection with SARS-CoV-2 occurred during the third trimester of pregnancy in the most documented studies, with no maternal deaths and a favorable clinical course in the neonates [25].

\section{PATHOGENESIS AND CLINICAL MANIFESTATIONS}

All ages are susceptible to COVID-19. The incubation period of COVID-19 is on average 5-6 days but can be as long as 14 days [26].

\section{Virus entry and host cell invasion}

The virus that is transmitted through respiratory droplets once, inside the body, S protein of the virus binds to host ACE- 2 receptors and enters host cells through endocytosis [27]. After binding of SARS-CoV-2 to the ACE-2, the S protein undergoes activation by cleavage of the S1/ S2 domain by the type 2 trans-membrane protease TMPRSS2 that causes conformational changes leading to viral and host cell membrane fusion [28]. Post membrane fusion, the virus enters the pulmonary alveolar epithelial cells and the viral contents are released in. Now inside the host cell, the virus undergoes replication through transcription and translation to synthesize new proteins [29]. Nucleocapsid (N) and membrane (M) proteins facilitate integration to the cellular endoplasmic reticulum. These newly formed nucleocapsids are then enclosed in the endoplasmic reticulum membrane and transported through exocytosis to the extracellular space and are ready to invade the adjacent epithelial cells as well as for providing fresh infective material for community transmission through respiratory droplets [27].

\section{Asymptomatic phase and upper respiratory tract infection}

SARS-CoV-2, which is obtained through respiratory aerosols, binds to ACE-2 receptors in the nasal epithelial cells in the upper respiratory tract [30]. The virus undergoes local replication and spread along with ciliate cell infection in the airways. This is the asymptomatic phase which lasts a couple of days and the immune response is limited during this phase. Compared to the throat, studies have shown higher viral loads in the nasal cavity, with no difference in viral burden between symptomatic and asymptomatic individuals [31].
Then, the virus migrates from the nasal epithelium to the upper respiratory tract through the conducting airways. There is a higher immune response during this stage involving the release of $\mathrm{C}-\mathrm{X}-\mathrm{C}$ motif chemokine ligand 10 (CXCL-10) and interferons (IFN- $\beta$ and IFN- $\lambda$ ) from virus-infected cells [32]. The majority of patients do not advance further than this phase as the expressed immune response is adequate to contain the spread of infection.

Cytokine storm, immune dysfunction, and progression to acute respiratory distress syndrome (ARDS)

Approximately one-fifth of all infected patients advance to the severe stage of COVID-19, characterized by cytokine storm and development of ARDS. The virus invades the lower respiratory tract and enters the type 2 alveolar epithelial cells through the host receptor ACE-2 and starts to undergo replication to produce more viral nucleocapsids. Many different cytokines and inflammatory markers are now produced by virus-laden pneumocytes, such as interleukins (IL-1, IL-6, IL-8, IL-120, and IL-12), factor- $\alpha$ (TNF- $\alpha$ ), IFN- $\lambda$ and IFN- $\beta$, CXCL-10, monocyte chemoattractant protein-1, and macrophage inflammatory protein- $1 \alpha$ (MIP- $1 \alpha$ ), this is known as a cytokine storm. For neutrophils, CD4 helper T cells, and CD8 cytotoxic $\mathrm{T}$ cells, this cytokine storm acts as a chemoattractant, which then begins to get sequestered in the lung tissue. These cells are responsible for fighting off the virus but also responsible for the consequent inflammation and lung injury. High concentrations of pro-inflammatory CD4 T cells and cytotoxic granules CD8 $\mathrm{T}$ cells were also determined, suggesting antiviral immune responses and overactivation of $\mathrm{T}$ cells leading to dysfunction of the immune system. With the release of new viral particles, the host cell undergoes apoptosis, which will then infect the neighboring type 2 alveolar epithelial cells in the same way. It contributes to the destruction of both type 1 and type 2 pneumocytes due to the persistent injury caused by the sequestered inflammatory cells and viral replication, ultimately causing diffuse alveolar damage resulting in ARDS [33].

There are various clinical presentations of COVID-19 (Table 1). Fever, dry cough, shortness of breath, fatigue, myalgia, nausea/vomiting or diarrhea, headache, and rhinorrhea are common symptoms in hospitalized patients. Aches and pains, nasal congestion, conjunctivitis, sore throat, loss of taste or smell, or skin rash or discoloration of fingers or toes are other symptoms that can affect certain patients. Typically, these symptoms are mild and begin gradually. In about $3 \%$ of people with COVID-19, anosmia or ageusia can be the sole presenting symptom. Non-classical symptoms, such as isolated gastrointestinal symptoms, can also occur in patients [34-38].

\section{RISK FACTORS, DIAGNOSIS, AND COMPLICATIONS}

The potential for serious risk from COVID-19 rises with age, with older adults at the highest risk for those aged 85 or older. In fact, 8 out of 10 deaths associated with COVID-19 recorded in the United States were among adults aged 65 years and older.

Table 1: Clinical spectrum of COVID-19 disease [37,38]

\begin{tabular}{|c|c|}
\hline Severity of disease & Presentation \\
\hline Asymptomatic & $\begin{array}{l}\text { No clinical symptoms, positive nasal swab } \\
\text { test, and normal chest X-ray. }\end{array}$ \\
\hline Mild illness & $\begin{array}{l}\text { Fever, sore throat, dry cough, malaise, and } \\
\text { body aches or nausea, vomiting, abdominal } \\
\text { pain, loose stools. }\end{array}$ \\
\hline Moderate illness & $\begin{array}{l}\text { Symptoms of pneumonia (persistent fever } \\
\text { and cough) without hypoxemia, significant } \\
\text { lesions on high-resolution computed } \\
\text { tomography of chest. }\end{array}$ \\
\hline Severe illness & Pneumonia with hypoxemia $\left(\mathrm{SpO}_{2}<92 \%\right)$ \\
\hline Critical state & $\begin{array}{l}\text { Acute respiratory distress syndrome, } \\
\text { along with shock, coagulation defects, } \\
\text { encephalopathy, heart failure, and acute } \\
\text { kidney injury. }\end{array}$ \\
\hline
\end{tabular}


COVID-19 is a novel disease. Other factors, such as underlying health conditions, may increase the risk of serious illness. People of any age with the following conditions are at increased risk: Immunocompromised state from a solid organ transplant, cancer, chronic kidney disease, asthma (moderate-to-severe), chronic obstructive pulmonary disease, cystic fibrosis, obesity, serious heart conditions such as heart failure, coronary artery disease, or cardiomyopathies, hypertension, type 2 diabetes mellitus, cerebrovascular disease, sickle cell disease, thalassemia, HIV, and neurologic conditions such as dementia, liver disease, pregnancy, smoking, use of corticosteroids, or use of other immune weakening medicines. People living in rural communities and people with disabilities, developmental and behavioral disorders, experiencing homelessness, racial, and ethnic minority groups should be extra cautious [39]. In a recently published retrospective cohort analysis study, it is observed that blood group 0 is associated with a decreased risk for contracting SARS-CoV-2 infection, whereas people with blood type $\mathrm{A}$ and $\mathrm{AB}$ are most vulnerable to the infection. $\mathrm{ABO}$ blood group is only considered as a risk factor for SARSCoV-2 infection but not for hospitalization or death from COVID-19 [40].

Usually, COVID-19 diagnosis is made using a polymerase chain reaction test through a nasal swab. However, due to the false-negative results of the SARS-CoV-2 polymerase chain reaction (PCR) test for nasal swabs, clinical, laboratory, and imaging findings can also be used to render a presumptive diagnosis.

\section{RT-PCR and serology}

Reverse transcription-PCR (RT-PCR) based SARS-CoV-2 RNA detection from respiratory samples (e.g., nasopharynx) is the standard for diagnosis. It amplifies viral genetic material obtained through nasal swab. Lower respiratory samples, such as bronchoalveolar lavage fluids, are more responsive than upper respiratory samples. Saliva may be an alternative specimen source [41]. Several serological tests and assays which include point-of-care and high throughput enzyme immunoassays can also aid in the diagnosis. IgM antibodies are measurable within 5 days of infection, with higher IgM levels during weeks 2-3 of disease, while IgG response is first seen around 14 days after onset of symptoms $[42,43]$.

\section{Laboratory findings}

These include basic blood work. The laboratory abnormalities seen in COVID-19 include elevated serum C-reactive protein, lactate dehydrogenase, alanine aminotransferase and aspartate aminotransferase, and low albumin levels. Lymphopenia (absolute lymphocyte count $<1.0 \times 109 / \mathrm{L}$ ) coupled with coagulopathy, slight prolongation of prothrombin, mild thrombocytopenia, and raised D-dimer values are the most common hematological abnormalities [44].

\section{Imaging}

The characteristic chest computed tomographic imaging abnormalities for COVID-19 are diffuse, peripheral ground-glass opacities [45].

Common complications among hospitalized patients with COVID-19 include pneumonia, ARDS, acute liver injury characterized by elevations in aspartate transaminase, alanine transaminase, and bilirubin, acute kidney injury, cardiac injury including elevated troponin, acute heart failure, dysrhythmias, and myocarditis; prothrombotic coagulopathy resulting in arterial thromboembolic and venous events, neurologic manifestations including impaired consciousness, acute cerebrovascular disease, and shock.

Rare complications among critically ill patients with COVID-19 include cytokine storm, rhabdomyolysis, multisystem inflammatory syndrome, macrophage activation syndrome, and pulmonary aspergillosis [46-48].

\section{TREATMENT}

There are currently no specific antiviral drugs or vaccines for SARS-CoV-2 management. In most cases, the treatment is primarily symptomatic and supportive. The following are the potential therapeutic options available for COVID-19.
Oxygen therapy through nasal cannula/simple face mask/venturi mask/ non-rebreather mask in patients with mild cases ( $\mathrm{SpO}_{2}$ levels of $94-97 \%$ in room air). In addition to oxygen treatment, antipyretics (acetaminophen) for fever and pain, oral fluids, and healthy diet on a symptomatic basis can be provided in mild cases [49]. High-flow nasal oxygen therapy (oxygen flow rate $30-40 \mathrm{~L} / \mathrm{min}$ ) can be provided to patients with moderate disease $\left(\mathrm{SpO}_{2}\right.$ of $90-94 \%$ in room air) in those cases where it is not possible to maintain $\mathrm{SpO}_{2}>92 \%$. Non-invasive continuous positive airway pressure ventilation may also be used for respiratory failure management [50]. Patients with severe ARDS disease must be started on oxygen therapy immediately at $5 \mathrm{~L} / \mathrm{min}$. Endotracheal intubation and mechanical ventilation are considered in cases of impairment of oxygen saturation below 90\% [49]. Extracorporeal membrane oxygenation (ECMO) for patients with refractory hypoxemia, despite endotracheal intubation and mechanical ventilation should be considered if feasible [51].

Broad-spectrum antibiotics, fluid resuscitation with isotonic crystalloids (normal saline [NS] and ringer's lactate), given at the rate of at least $30 \mathrm{~mL} / \mathrm{kg}$ in the first $3 \mathrm{~h}$ and vasopressors for prevention/ management of shock and peripheral hypoperfusion. Dobutamine is the drug of choice if the patient shows signs of poor perfusion and cardiogenic shock, despite the vasopressor and antibiotic support [49].

\section{Other drug therapies}

Antibiotics

They are effective in preventing or managing secondary bacterial infections and sepsis but in preventing viral infections. Azithromycin is effective in preventing pulmonary infections, in addition to having a significant anti-inflammatory effect on the airways [52].

\section{Antiviral drugs}

Most antiviral drugs undergoing clinical testing in patients with COVID-19 are repurposed, antiviral agents.

Remdesivir is a broad-spectrum antiviral agent that inhibits the action of viral RNA-dependent RNA polymerase [53]. It can be considered in patients with moderate illness at a loading dose of $200 \mathrm{mg}$ intravenously over 1-2 h on day 1 followed by $100 \mathrm{mg}$ intravenously for 5-10 days. Contraindications to the use of remdesivir include use in children, pregnant or lactating females, and patients with severe hepatic or renal impairment [49]. The recently concluded ACTT-1 trial final report on remdesivir for COVID-19 treatment deduced that remdesivir was superior to placebo in lowering recovery time and infection of the lower respiratory tract in adults who were hospitalized. The estimates of mortality were also lower in the drug group [54]. In contradiction to the ACTT-1 trial results, the interim WHO SOLIDARITY trial results concluded that remdesivir has little or no effect on hospitalized COVID-19 patients in terms of overall mortality, initiation of ventilation, and duration of hospital stay [55].

\section{Lopinavir/ritonavir}

LPV has been shown to inhibit the coronavirus protease activity The effective dose of LPV is $400 \mathrm{mg}$ orally every $12 \mathrm{~h}$ and was initially seen as a promising therapeutic choice for COVID-19, but no definitive benefit of LPV/RTV therapy compared to the routine management protocol was found in a recent randomized controlled trial (RCT) [56].

\section{Favipiravir}

It shows activity against RNA viruses by selective inhibition of the viral RNA-dependent RNA polymerase. It is used in mild-to-moderate cases with COVID-19. The recommended starting dose is $1800 \mathrm{mg}$ twice daily on day 1 followed by $800 \mathrm{mg}$ twice daily on day 14 . It is associated with the rapid reduction of the viral load and an early symptomatic improvement [57].

\section{Immunomodulators}

These drugs act by modulating the inflammatory response in patients with COVID-19. Monoclonal antibodies directed againstinflammatorymediators, 
such as interleukin 1, interleukin 6, interferon-gamma, and complement factor $5 \mathrm{a}$, all target the overactive inflammatory response following SARSCoV-2 infection to prevent organ damage [58]. Of these, tocilizumab and sarilumab are best-studied interleukin 6 inhibitors. Tocilizumab is a humanized IgG1 monoclonal antibody. It may be considered in patients with moderate disease who have elevated inflammatory markers (IL-6) with a gradual increase in oxygen demand and patients with mechanical ventilation. The dosage is $8 \mathrm{mg} / \mathrm{kg}$ with a maximum dose of $800 \mathrm{mg}$ at one time can be given slowly in $100 \mathrm{~mL}$ NS over $1 \mathrm{~h}$ and can be repeated once after $12-24 \mathrm{~h}$ if needed $[59,60]$. Tyrosine kinase inhibitors, such as imatinib, are also being investigated for their ability to inhibit vascular pulmonary leakage in individuals with COVID-19.

\section{Chloroquine and hydroxychloroquine (HCQ)}

Chloroquine, an anti-malarial drug (at the dose, $500 \mathrm{mg}$, every $12 \mathrm{~h}$ ), blocks the virus infection by an increase in the endosomal $\mathrm{pH}$ required for virus/cell fusion. Efficacy in reducing exacerbation of COVID-19 pneumonia as well as accelerated viral and symptomatic clearance has been exemplified [61]. HCQ (200 mg every $12 \mathrm{~h}$ ) is a chloroquine analog with an enhanced safety profile and anti-SARS-CoV effect. It is also shown to be associated with significant viral load reduction [62]. Adverse effects are common, most notably QT prolongation, with an increased risk of cardiac complications in an already vulnerable population [63].

On June 17, 2020, WHO announced the termination of HCQ drug from the Solidarity Trial, which is an international clinical trial to help find an effective treatment for COVID-19, launched by WHO and partners. The trials have shown that HCQ does not result in the reduction of mortality of hospitalized COVID-19 patients when compared with standard of care [64].

\section{Corticosteroids}

Small doses of methylprednisolone (not exceeding $0.5-1 \mathrm{mg} / \mathrm{kg} / \mathrm{d}$ in moderate cases and $1-2 \mathrm{mg} / \mathrm{kg} / \mathrm{d}$ in severe cases) are indicated in patients with deteriorating oxygen saturation. High doses should not be recommended due to immunosuppression by steroids, which delays viral clearance [65]. Recently, dexamethasone has also been found to be effective for decreasing mortality in severe and critically ill cases [66].

The panel reviewed eight RCTs (7184 patients) on July 17, 2020, to compare systemic corticosteroids to usual COVID-19 treatments. The RECOVERY study, the largest of the seven studies in which mortality data by subgroup (severe and non-severe) were available, assessed the effects of dexamethasone $6 \mathrm{mg}$ administered once daily (oral or intravenous) for up to 10 days in 6425 hospitalized patients in the United Kingdom (2104 were randomized to dexamethasone and 4321 were randomized to usual care).

The WHO has issued two recommendations on the use of corticosteroids: A strong recommendation for systemic (i.e., intravenous or oral) corticosteroid treatment (i.e., $6 \mathrm{mg}$ oral or intravenous dexamethasone daily or $50 \mathrm{mg}$ intravenous hydrocortisone every $8 \mathrm{~h}$ ) for 7-10 days in patients with severe and critical COVID-19 and a conditional proposal not to use corticosteroids in patients with non-severe COVID-19. This guidance was prompted by the publication of the preliminary report of the RECOVERY trial [67] on June 22, 2020, to assess the effect of dexamethasone in hospitalized patients with COVID-19 carried out by the University of Oxford.

Evidence from RCTs and prospective meta-analysis of RCTs performed by the WHO Rapid Evidence Evaluation for COVID-19 Therapies Working Group [68] and two previously published meta-analyses and pooled data on the safety of systemic corticosteroids were analyzed in different but related patient populations to establish the recommendations $[69,70]$ (Table 2).

\section{Primary outcome of RECOVERY trial}

Mortality at 28 days was significantly lower in the dexamethasone group than in the usual care group, with deaths reported in $22.9 \%$ and $25.7 \%$ patients, respectively. The mortality rate among patients receiving invasive mechanical ventilation and those receiving oxygen without invasive mechanical ventilation was lower in the dexamethasone group than in the normal treatment group, but there was no significant effect of dexamethasone in patients receiving no respiratory support at randomization. The higher mortality benefit in response to dexamethasone therapy was seen in patients with longer duration of symptoms who were more likely to be randomized to undergo invasive mechanical ventilation and has been associated with decreased 28-days mortality for those with symptoms for more than 7 days but not for those with a more recent onset of symptoms.

\section{Secondary outcomes of RECOVERY trial}

Patients in the dexamethasone group had a shorter duration of hospitalization than those in the usual care group and a greater probability of discharge alive within 28 days. The greatest discharge effect within 28 days was found in patients undergoing invasive mechanical ventilation than in patients who did not receive invasive mechanical ventilation at randomization. The number of patients progressing to pre-described secondary outcome of invasive mechanical ventilation or death was lower in the dexamethasone group. Analyses are underway on cause-specific mortality, renal dialysis or hemofiltration requirements, and ventilation periods.

Many COVID-19 treatment recommendations stated before the completion of the trial that the use of glucocorticoids has been either contraindicated or just not recommended [71]. But then, the RECOVERY study offers proof that dexamethasone therapy is effective in reducing the 28-days mortality rate in respiratory supporting patients with COVID-19. No gain (and the risk of harm) was observed in the study among patients who did not need oxygen.

\section{Plasma therapy}

Patients are treated with plasma collected from individuals within 2 weeks after recovery from COVID-19 [9]. Some important criteria for this technique are sufficient antibody titer in convalescent plasma, ABO compatibility, and cross-matching of donor plasma. The dose varies from 4 to $13 \mathrm{~mL} / \mathrm{kg}$, and a single dose of $200 \mathrm{~mL}$ is typically given slowly over $2 \mathrm{~h}$. This therapy is considered in patients with severe disease [49].

\section{Other supplementary therapies}

Thromboembolic prophylaxis with subcutaneous low molecular weight heparin (e.g., enoxaparin $40 \mathrm{mg} \mathrm{SC}$ ) is recommended for all hospitalized patients with moderate (once daily) to severe (twice daily) COVID-19 [72]. In addition, intravenous transplantation of ACE2-mesenchymal stem cells (MSCs) and blocking of Fc receptors with immunoglobulin (IVIG) are also potential therapeutic strategies for severe COVID-19 [73]. There are ongoing studies on the use of Ivermectin alone or in combination with doxycycline to mitigate the risk and also a suggested combinatorial therapy (Ivermectin, Famotidine, and Doxycycline) for the treatment of COVID-19 [74]. For patients diagnosed with COVID-19 suffering from fear and anxiety, psychological counseling must be provided [49].

In another recently published study, they demonstrated that nitric oxide (NO) can inhibit the viral replication by targeting the SARSCoV-2 main protease in vitro. In patients with the SARS, NO which is a broad-spectrum antimicrobial and a potent vasodilator has proven to be effective in reducing SARS-CoV replication and hypoxia. It has been concluded, based on a few previous studies, that NO can be used for clinical use in the treatment of COVID-19 [75]. Vaccines save millions of lives each year. More than 100 vaccine candidates for COVID-19 are currently being developed, many of which are in the human trial process.

The infections that may worsen with corticosteroids should be considered. For example, Strongyloides stercoralis hyperinfection associated with corticosteroid therapy and with a $1 / 3^{\text {rd }}$ mortality reduction conferred by dexamethasone in ventilated patients with 


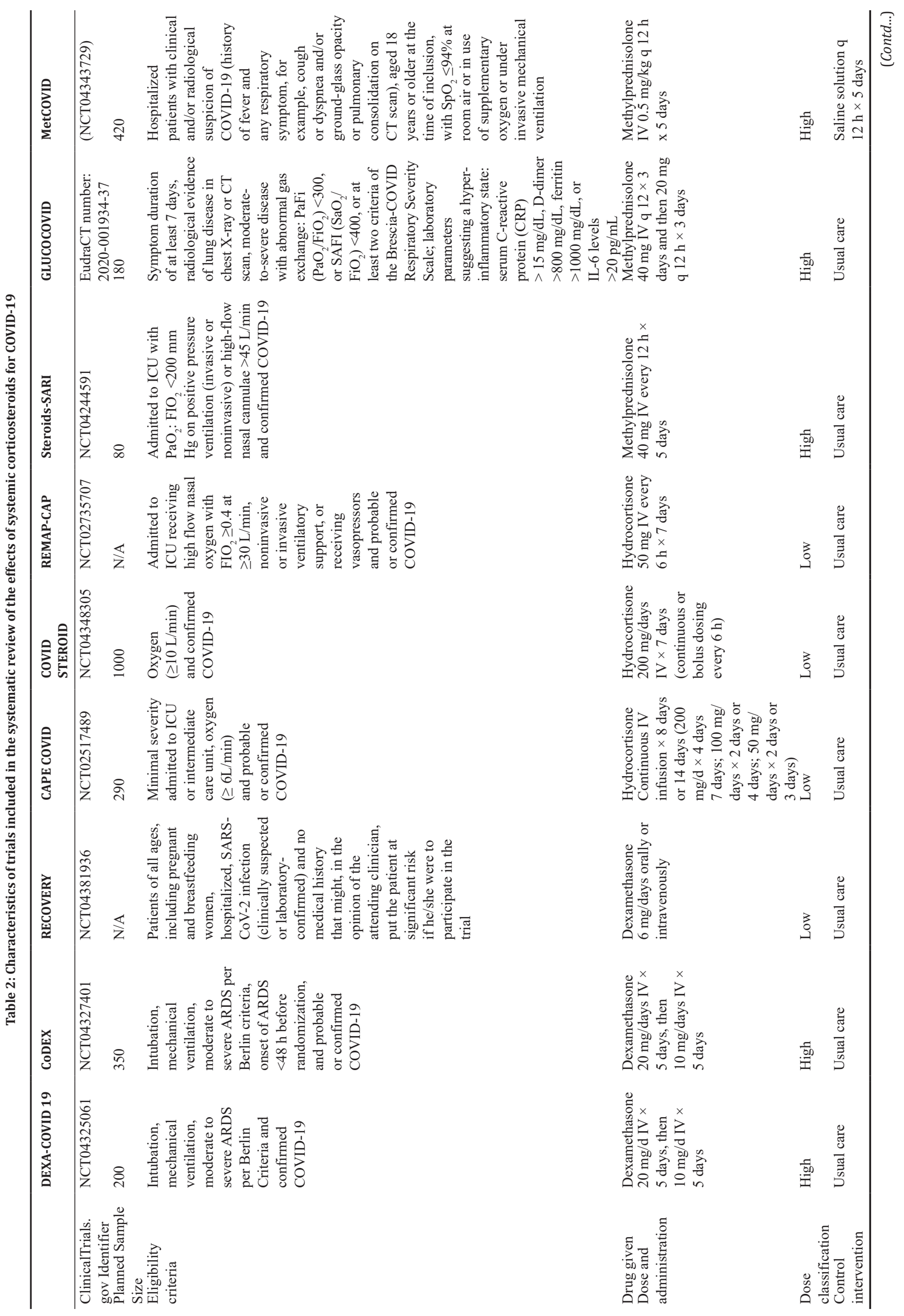




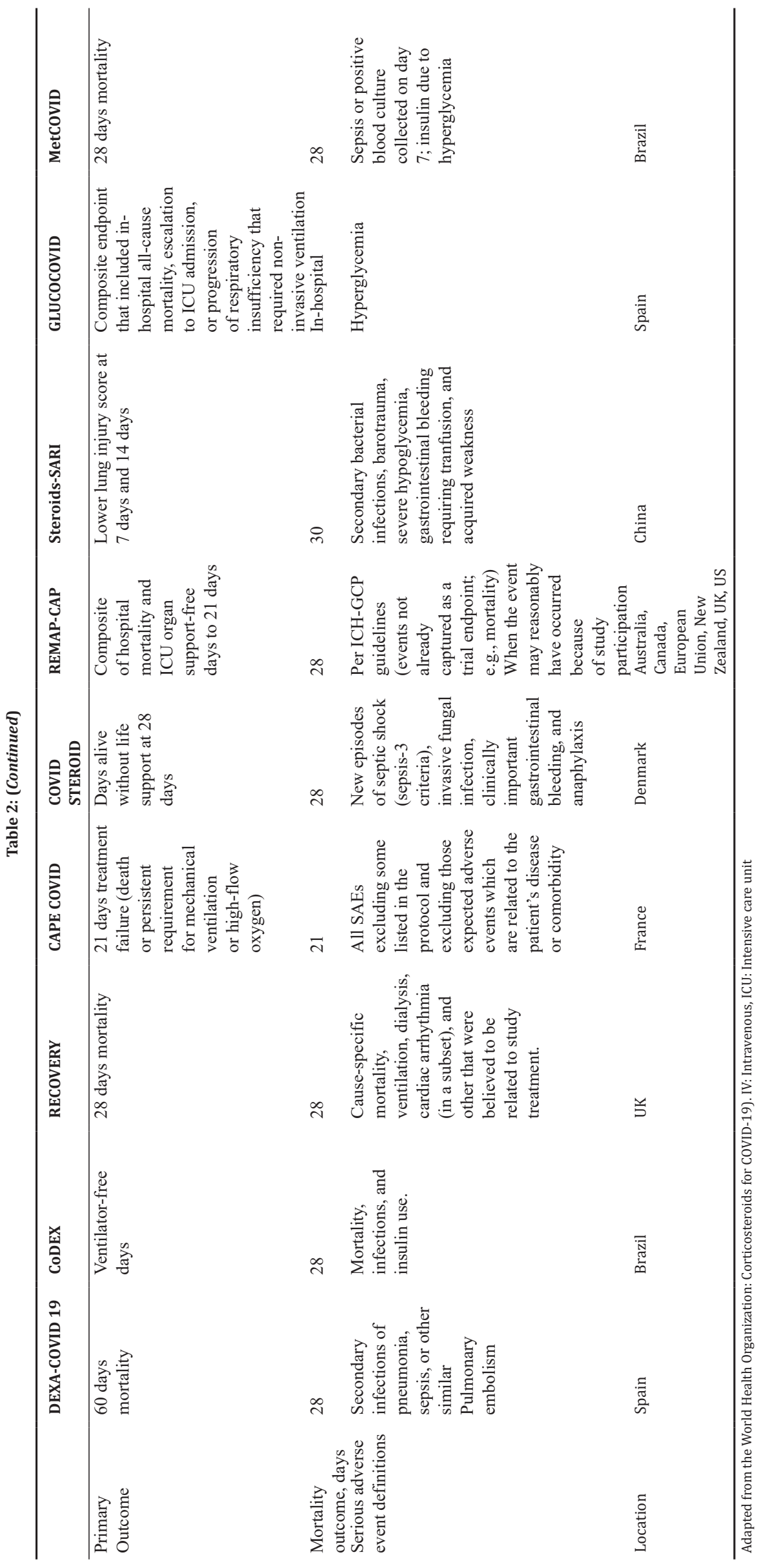


COVID-19, there may be at increased risk of acquiring Coronavirus Associated Pulmonary Aspergillosis (CAPA).

\section{SECONDARY INFECTIONS IN COVID-19}

Secondary infections are aided by exposure to a pathogen along with a compromised immune system as a result of the primary infection. The only choice for such patients is to strengthen their immune system and avoid the progression of infection that could result in septic shock or even death. Hospitals are a common source of pathogens that cause secondary infections [76]. Although secondary infections occur as a result of primary infection, multiple pathogens of viral, bacterial, or fungal source cause co-infections and occur simultaneously [77]

The secondary infections occurring in COVID-19 were respiratory, bloodstream, and urinary tract infections. A total of 52, 20, and 7 pathogens were confirmed in the respiratory, bloodstream, and urinary tract infection patients, respectively. Most of which were gram-negative, following by gram-positive bacteria, virus, fungi, and others (Table 3). The secondary infection rate in critical patients is much higher than that in severe patients with COVID-19 [78].

\section{CAPA}

Aspergillus is an opportunistic fungal pathogen that can cause debilitating disease in immunocompromised hosts, including those with hematological malignancies. Aspergillus is an air-borne pathogen that places the lungs at the forefront of defense. Recently, severe viral pulmonary infections, including COVID-19 have shown to be associated with an increased risk for invasive pulmonary aspergillosis (IPA) [79]. Fungi belonging to genus Aspergillus are ubiquitous, thermotolerant (which can withstand temperature up to $37^{\circ} \mathrm{C}$, spore survival temperature up to $50^{\circ} \mathrm{C}$ ) and favorable for humid conditions. They mainly grow on decaying vegetations, basements of houses, saunas, etc. Aspergillus causes a wide range of lung diseases such as pulmonary aspergillosis [80]. The main reason for developing IPA is pulmonary epithelial damage and long-term systemic steroids [81].

\section{Prevalence of CAPA}

Many of the prevalence studies conducted are from China. Research in Jiangsu Province found that $23.3 \%$ of patients had Aspergillus-positive throat swab [82]. Other research in China revealed that $27 \%$ of patients had a fungal infection and another study reported that $7.7 \%$ of patients developed IPA. However, none of these studies used standard diagnostic rules and defined definitions for the identification of CAPA. In fact, the gold standard test - galactomannan test for fungal infection is scarcely available in China [83]. It can also be concluded that these findings are far from the actual prevalence of the CAPA. However, recently, some studies and case series from Europe have reported a higher

Table 3: Causative pathogen species in COVID-19

\begin{tabular}{ll}
\hline Secondary infections in COVID-19 \\
\hline Causative pathogen & Organisms \\
\hline Bacterium & Mycobacterium intracellulare \\
& Chryseobacterium \\
& Pseudomonas aeruginosa \\
& Escherichia coli \\
& Stenotrophomonas maltophilia \\
& Enterococcus faecalis \\
& Staphylococcus \\
& Acinetobacter baumannii \\
& Enterococcus faecium \\
& Mycoplasma hominis \\
Virus & HHV6 \\
& HSV1 \\
Fungi & Penicillium \\
& Aspergillus \\
\hline
\end{tabular}

prevalence of CAPA in COVID-19 patients with ARDS, ranging from 25\% to $30 \%$ [84]. The development of CAPA was surprisingly rapid, with a median of 6 days and a span of 3-28 days after intensive care unit (ICU) admittance. Among 35 CAPA cases reported, the overall mortality rate was $63 \%$; of particular importance was the $100 \%$ fatality rate of those with underlying diseases reported from the Netherlands, while the two patients without underlying conditions both survived [85]. Overall, the most prevalent Aspergillus spp. appeared to be Aspergillus fumigatus isolated among respiratory samples with a positive culture, followed by Aspergillus flavus.

\section{Risk factors}

Risk factors that predispose patients with COVID-19 to develop secondary pulmonary aspergillosis are close to those reported for superinfections with influenza-IPA [81]. The most important risk factors include severe lung damage, the use of corticosteroids in those with ARDS, the widespread use of broad-spectrum antibiotics in ICUs [86], and the presence of comorbidities such as hypertension, coronary heart diseases, and diabetes increase the risk of infection overall [87], while the structural lung damage caused by COPD or asthma may particularly predispose patients to develop IPA [85]. It has also been proposed that toxicity due to antibiotics (disrupts gut microbiome steady-state composition, which allows fungi to thrive), cytokine storm due to viral antigen, and hypoxia-induced lung injury due to mechanical ventilation, high airway pressure can all result in pulmonary fibrosis. Patients with interstitial pulmonary fibrosis, who may require long-term systemic steroids, can develop IPA long after the acute phase has gone [88].

\section{Pathogenesis}

Pathogenesis of CAPA is complex. A molecular understanding of physiology is needed to identify the mechanism by which the infection of COVID-19 promotes the development of IPA. The receptor and signaling pathways involved in the immune recognition of Aspergillus are well established [89].

Two possible mechanisms can be presumed and are likely to characterize the output of ARDS and, therefore, CAPA. The first involves the release of dangerous molecular patterns (DAMPs), signal molecules released by dying or damaged cells that act as endogenous danger signals to accelerate and boost the immune and inflammatory response that leads to lung injury [90]; DAMPs have also been shown to control inflammation and [91] intensify the inflammatory response by integrating with Toll-like receptors in experimental aspergillosis [92]. This underlying notion could help to explain fungal pathogenesis in intensifying inflammation conditions such as those seen in COVID-19 patients. The second potential mechanism involves the pathways needed to activate antiviral immunity. Hyperactivation of the IL-1 pathway induced by the SARS-CoV-2 infection establishes a highly permissive inflammatory environment that favors fungal pathogenesis. In addition to IL-1, increased levels of IL-6 have also been observed in epithelial cells after infection with A. fumigatus, with an effect on immune cell function indicating that infection can lead to increased cytokine levels in patients with severe COVID-19 [93].

All in all, decline in immune cells, especially T-lymphocytes (lymphocytopenia) and defective immune responses to SARS-CoV-2, has been shown to permit unregulated viral replication, resulting in hyper-inflammation, and serious complications such as ARDS [94], in addition to creating favorable conditions for the acquisition of secondary infections such as CAPA.

\section{Diagnosing CAPA}

The diagnosis of pulmonary aspergillosis is challenging, with culture having low sensitivity [95]. At present, the optimal diagnostic algorithm for the diagnosis of CAPA is uncertain and is being actively investigated in an ongoing multinational exploratory trial in collaboration with the European Confederation of Medical Mycology (ECMM). To date, the 
most prevalent approaches include attempting to recover Aspergillus spp. on culture media of bronchoalveolar fluid (BALF) and tracheal aspirate, as well as utilizing serologic biomarker testing such as the conventional Galactomannan (GM) which is a more sensitive test in patients with neutropenia, from BALF, tracheal aspirate and serum specimens. Aspergillus PCR, serum $(1 \rightarrow 3)-\beta$-D-glucan, the Aspergillus galactomannan lateral flow assay, and the Aspergillus-specific lateralflow device test are other diagnostic tests that may prove useful. Thus, the most promising diagnostic modalities tend to be BALF, tracheal aspirate culture, and traditional GM testing by BALF. Testing from blood samples may be safer and optimal [96].

A restricted role for bronchoscopy has been recommended in COVID-19 because it is an aerosol-generating procedure and it is recommended in critically ill patients with COVID-19 who are suspected of secondary infection, including fungal diagnostic workup [97].

\section{Current treatment standards of CAPA}

Whether antifungal therapy leads to any survival benefits in COVID-19 patients with IPA is not known, but still, once the diagnosis of CAPA is suspected, antifungal therapy should be started. Voriconazole remains the drug of choice [98]. However, in addition to its small therapeutic window and the need for therapeutic drug monitoring to ensure effectiveness and avoid drug-drug interactions, the use of voriconazole may be especially limited. It is one of the drugs most widely associated with major drug-drug interactions as it is metabolized by CYP2C19, CYP2C9, and CYP3A4 [99]. Isavuconazole and liposomal amphotericin $B$ are the key alternative therapeutic choices for IPA in the ICU [100]. Compared to voriconazole, isavuconazole is associated with fewer adverse effects and shows a more favorable pharmacokinetic profile. However, it is also metabolized through CYP3A4, although drug-drug interactions are generally less a problem with isavuconazole than with voriconazole [101].

Liposomal amphotericin B is a broadly effective alternative treatment choice, butitsometimes complicatesinitiationorinvolvesdiscontinuation of this antifungal agent in patients with renal insufficiency. For patients infected with SARS-CoV-2, which has demonstrated renal tropism and has been identified as a frequent cause of kidney injury, this concern is extremely crucial [102]. Although itraconazole is now rarely used for the treatment of invasive aspergillosis, some antiviral activity has been shown to be successful in the feline coronavirus model, specifically as a cholesterol transport inhibitor [103]. Furthermore, its latest oral SUBA formulation has excellent bioavailability [104], and itraconazole could therefore be an alternative choice for the treatment of IPA associated with COVID-19, although it shares the drug-drug interaction problems with other triazoles.

At present, in progress, new antifungal medications, namely fosmanogepix and olorofim, which may have similar effects without the same burden of drug-drug interactions and toxicity and may thus overcome the drawbacks of currently available antifungals and become the preferred treatment choices in the near future. If the documented high incidence of COVID-19-associated IPA in ICU patients is validated in larger studies, there may be a rationale for prophylaxis trials, for which not only triazoles and nebulized liposomal amphotericin [96], but also another novel antifungal currently under research, rezafungin (i.e., once weekly echinocandin with improved activity against Aspergillus spp.), maybe a candidate [105].

\section{Photodynamic therapy}

Most of the patients admitted to hospitals with COVID-19 infection have contracted bacterial co-infections (pneumococcal pneumonia caused by Streptococcus pneumoniae and infections caused by Streptococcus aureus).

Photodynamic treatment does not specifically destroy the virus yet destroys microorganisms in the respiratory tract using light and a photosensitizing chemical substance. The photodynamic therapy generates reactive oxygen species and oxygen molecules which help in damaging the targets of the virus. Specific pharyngotonsillitis photodynamic therapy can not only help in reducing the number of microorganisms present in the oropharynx but also in preventing these microorganisms from penetrating the mucosa. Phagocytes (which engulf harmful foreign organisms) are also activated by this treatment, thereby preventing the proliferation of microorganisms in the mucosa.

A photodynamic therapy test against bacterial pneumonia was performed by the researchers. In this test, the scientists used a 780-nanometer wavelength extracorporeal illumination (light source) and used indocyanine green as a photosensitizer, which was supplied through nebulizers to the patients. The experiment concluded that in the group that obtained the photodynamic therapy, no deaths were reported, while $60 \%$ of participants in the control group died. Photodynamic therapy can be used to treat secondary infections in patients with COVID-19, either as a single therapy or as an antibiotic adjuvant [106].

\section{PREVENTIVE MEASURES FOR COVID-19}

The only way one can protect themselves from contracting the COVID-19 infection is by following preventive measures such as practicing good hand hygiene. Restrictions on close interaction between infected persons and healthy individuals is crucial for breaking the chains of the transmission of the virus. Identifying the suspected cases as soon as possible, testing, and also isolating the infectious cases is the best preventive measures for the spread of the virus so that they can be quarantined [107]. Incubation period, which means the time interval between exposure to virus and onset of symptoms of COVID-19 is 5-6 days on average, but can also be up to 14 days [108]. Thus, 14 days for the quarantine to be in a place from the last exposure to a confirmed case. If it is not possible for a person to be in quarantine in a separate space, then self-quarantine for 14 days at home is necessary. Support may be required during the use of physical distancing measures for avoiding the spread of the virus in those who are self-quarantined. Masks can be used as one of the preventive measures in which frequent hand washing, physical distancing whenever required, respiratory etiquette, environmental cleaning, and disinfection. Other precautions include indoor gatherings can be avoided as much as possible. Avoid keeping in touch with animals and their excretions or droppings. In areas with COVID-19 community transmission, it is advised that the health personnel's and caregivers working in the clinical sector should wear a medical mask continuously during every activity all through the entire shift [109] and should wear an N95, FFP2, or FFP3 respirator, where aerosol-generating procedures are performed [110]. Promoting safe individual practices at the workplace, engage workers in providing feedback on the preventive measures and their effectiveness by providing the videos, posters, and electronic message boards to enhance the awareness of COVID-19 [111].

\section{IMMUNITY FOLLOWING SARS-COV-2 INFECTION}

Specific antibodies and cell-mediated responses are induced following SARS-CoV-2 infection. Preliminary evidence demonstrates that some of these responses are safeguarding, but this remains to be established definitively. Besides, it is unclear if all infected patients have a protective immune response and if so, how long it would last to have a protective effect.

\section{Humoral immunity}

Protective immunity evidence following COVID-19 is emerging. There is emerging protective immunity evidence following COVID-19. Case series testing convalescent plasma for the treatment of COVID-19 reported neutralizing activity in the plasma of recovered patients, which seemed to be transmitted to recipients following a plasma infusion [112]. Similarly, in another study of 23 patients who recovered from COVID-19, spike protein and nucleocapsid protein receptor binding antibodies were identified by enzyme-linked immunosorbent 
assay (ELISA) in most patients within 14 days of onset of symptoms; ELISA antibody titers were associated with neutralizing activity. Some results, however, indicate that the magnitude of antibody response may be correlated with disease severity and detectable neutralizing antibodies may not be mounted in patients with mild infection. In addition, the durability of neutralizing activity following infection is uncertain, as neutralizing antibodies decline over several months after infection $[113,114]$.

\section{Cell-mediated immunity}

SARS-CoV-2 specific CD4 and CD8 T cell responses have also been identified in studies in patients who have recovered from COVID-19 and in individuals who have received an investigational SARS-CoV-2 vaccine, indicating the potential for a durable $\mathrm{T}$ cell immune response $[115,116]$.

\section{RISK OF REINFECTION}

Overall, the short-term risk of reinfection (e.g., during the first few months following initial infection) tends to be minimal. However, occasional cases of probable reinfection have been reported. As an example, an asymptomatic case in Hong Kong identified two distinct strains, suggesting two distinct infections of SARS-CoV-2 on travel-related screening, 5 months after mild laboratory-confirmed COVID-19 [117]. The second infection, however, was asymptomatic, giving rise to the possibility that immunity from an initial infection could attenuate the seriousness of reinfection even if it is not prevented [118]. However, a recent published study mentioned that SARS-CoV-2 reinfection resulted in worse disease than the first infection in two patients, requiring oxygen support and hospitalization. This information is key in understanding the immunity following infection with SARS-CoV-2 [119].

Simply having a positive SARS-CoV-2 viral test after recovery does not inherently mean reinfection; a sequence that indicates a different strain at the time of presumptive reinfection is required to make a distinction. Specifically, the study from the Korea Centers for Disease Control and Prevention found that patients with COVID-19 who had a positive repeat RNA test after they had previously been cleared of isolation were unable to isolate the infectious virus in any of 108 patients examined [118].

\section{CONCLUSION}

As the world waits for a clinically approved vaccine, prevention is the best way to combat COVID-19. There are no standard therapeutic regimens to handle the spread of SARS-CoV-2. It is important to conduct large randomized trials for the use of repurposed drugs and more comparative shreds of evidence are to be established to reduce the morbidity and mortality in COVID-19 patients. As dexamethasone is on the list of essential medicines of the WHO, it is important to accentuate the need for future analyses of the evidence for corticosteroid use in COVID-19, such as its long-term effects and their use in non-severe patients, as they remain unclear and may be studied further. As additional therapies are under development for COVID-19, notably novel immunomodulators, it is important to ascertain how these interact with systemic corticosteroids; other endemic infections that may worsen with corticosteroids should be considered, especially CAPA in patients who are on invasive ventilation, which should emphasize the need for further fungal surveillance.

\section{AUTHORS' CONTRIBUTIONS}

All the authors contributed equally in the preparation of this manuscript.

\section{CONFLICTS OF INTEREST}

The authors declare no conflicts of interest.

\section{AUTHORS' FUNDING}

Nil.

\section{REFERENCES}

1. Chan JF, Yuan S, Kok KH, To KK, Chu H, Yang J, et al. A familial cluster of pneumonia associated with the 2019 novel coronavirus indicating person-to-person transmission: A study of a family cluster. Lancet 2020;395:514-23.

2. Lu H, Stratton CW, Tang YW. Outbreak of pneumonia of unknown etiology in Wuhan, China: The mystery and the miracle. J Med Virol 2020;92:401-2.

3. Shereen MA, Khan S, Kazmi A, Bashir N, Siddique R. COVID-19 infection: Origin, transmission, and characteristics of human corona viruses. J Adv Res 2020;24:91-8.

4. Zhong NS, Zheng BJ, Li YM, Poon LL, Xie ZH, Chan KH, et al. Epidemiology and cause of severe acute respiratory syndrome (SARS) in Guangdong, people's republic of China, in February, 2003. Lancet 2003;362:1353-8.

5. Wang N, Shi X, Jiang L, Zhang S, Wang D, Tong P, et al. Structure of MERS-CoV spike receptor-binding domain complexed with human receptor DPP4. Cell Res 2013;23:986-93.

6. Masters PS. The molecular biology of corona viruses. Adv Virus Res 2006;66:193-292

7. Kramer A, Schwebke I, Kampf G. How long do nosocomial pathogens persist on inanimate surfaces? A systematic review. BMC Infect Dis 2006;6:130.

8. Lu R, Zhao X, Li J, Niu P, Yang B, Wu H, et al. Genomic characterisation and epidemiology of 2019 novel coronavirus: Implications for virus origins and receptor binding. Lancet 2020;395:565-74.

9. Zhou P, Lou YX, Wang XG, Hu B, Zhang L, Zhang W, et al. A pneumonia outbreak associated with a new coronavirus of probable bat origin. Nature 2020;579:270-3.

10. Boni MF, Lemey $\mathrm{P}$, Jiang X, Lam TT, Perry B, Castoe $\mathrm{T}$, et al. Evolutionary origins of the SARS-CoV-2 sarbecovirus lineage responsible for the COVID-19 pandemic. Nat Microbiol 2020;5: 1408-17.

11. World Health Organization. Coronavirus Disease (COVID-19) Dashboard. Geneva: World Health Organization. Available from: https://www.covid19.who.int.

12. Havers FP, Reed C, Lim T, Montgomery JM, Klena JD, Hall AJ, et al. Seroprevalence of antibodies to SARS-CoV-2 in 10 sites in the United States, March 23-May 12, 2020. JAMA Intern Med 2020;2020:4130.

13. Mantovani A, Rinaldi E, Zusi C, Beatrice G, Saccomani MD, Dalbeni A. Coronavirus disease 2019 (COVID-19) in children and/or adolescents: A meta-analysis. Pediatr Res 2020;2020:1015.

14. Zaigham M, Andersson O. Maternal and perinatal outcomes with COVID-19: A systematic review of 108 pregnancies. Acta Obstet Gynecol Scand 2020;99:823-9.

15. Mahase E. China coronavirus: What do we know so far? BMJ 2020;368:m308.

16. Rodriguez-Morales AJ, Bonilla-Aldana DK, Balbin-Ramon GJ, Rabaan AA, Sah R, Paniz-Mondolfi A, et al. History is repeating itself: Probable zoonotic spillover as the cause of the 2019 novel Coronavirus Epidemic. Infez Med 2020;28:3-5.

17. Lam TT, Shum MH, Zhu HC, Tong YG, Ni XB, Liao YS. Identifying SARS-CoV-2 related coronaviruses in Malayan pangolins. Nature 2020;583:282-5.

18. Chu DK, Akl EA, Duda S, Solo K, Yaacoub S, Schünemann HJ, et al. Physical distancing, face masks, and eye protection to prevent personto-person transmission of SARS-CoV-2 and COVID-19: A systematic review and meta-analysis. Lancet 2020;395:1973-87.

19. Chia PY, Coleman KK, Tan YK, Ong SW, Gum M, Lau SK, et al. Detection of air and surface contamination by SARS-CoV-2 in hospital rooms of infected patients. Nat Commun 2020;11:2800.

20. Riddell S, Goldie S, Hill A, Eagles D, Drew TW. The effect of temperature on persistence of SARS-CoV-2 on common surfaces. Virol J 2020;17:145.

21. Lewis D. Is the coronavirus airborne? Experts can't agree. Nature 2020;580:175.

22. Leclerc QJ, Fuller NM, Knight LE, Funk S, Knight GM, CMMID COVID-19 Working Group. What settings have been linked to SARSCoV-2 transmission clusters? Wellcome Open Res 2020;5:83.

23. Van Doremalen N, Bushmaker T, Morris DH, Holbrook MG, Gamble A, Williamson BN, et al. Aerosol and surface stability of SARS-CoV-2 as compared with SARS-CoV-1. N Engl J Med 2020;382:1564-7.

24. Rothe C, Schunk M, Sothmann P, Bretzel G, Froeschl G, Wallrauch C, et al. Transmission of 2019-nCoV infection from an asymptomatic contact in Germany. N Engl J Med 2020;382:970-1.

25. Chen H, Guo J, Wang C, Luo F, Yu X, Zhang W, et al. Clinical 
characteristics and intrauterine vertical transmission potential of COVID-19 infection in nine pregnant women: A retrospective review of medical records. Lancet 2020;395:809-15.

26. Lauer SA, Grantz KH, Bi Q, Jones FK, Zheng Q, Meredith HR, et al. The incubation period of coronavirus disease 2019 (COVID-19) from publicly reported confirmed cases: Estimation and application. Ann Int Med 2020;172:577-82.

27. Cascella M, Rajnik M, Cuomo A, Dulebohn SC, Di Napoli R. Features, Evaluation, and Treatment of Coronavirus (COVID-19). Treasure Island, FL: StatPearls Publishing; 2020.

28. Belouzard S, Millet JK, Licitra BN, Whittaker GR. Mechanisms of coronavirus cell entry mediated by the viral spike protein. Viruses 2012;4:1011-33.

29. Yang N, Shen HM. Targeting the endocytic pathway and autophagy process as a novel therapeutic strategy in COVID-19. Int J Biol Sci 2020;16:1724-31

30. Hoffmann M, Kleine-Weber H, Schroeder S, Krüger N, Herrler T, Erichsen S, et al. SARS-CoV-2 cell entry depends on ACE2 and TMPRSS2 and is blocked by a clinically proven protease inhibitor. Cell 2020;181:271-80.e8.

31. Zou L, Ruan F, Huang M, Liang L, Huang H, Hong Z, et al. SARS$\mathrm{CoV}-2$ viral load in upper respiratory specimens of infected patients. $\mathrm{N}$ Engl J Med 2020;382:1177-9.

32. Tang NL, Chan PK, Wong CK, To KF, Wu AK, Sung YM, et al. Early enhanced expression of interferon-inducible protein-10 (CXCL10) and other chemokines predicts adverse outcome in severe acute respiratory syndrome. Clin Chem 2005;51:2333-40.

33. Xu Z, Shi L, Wang Y, Zhang J, Huang L, Zhang C, et al. Pathological findings of COVID-19 associated with acute respiratory distress syndrome. Lancet Respir Med 2020;8:420-2

34. Goyal P, Choi JJ, Pinheiro LC, Schenck EJ, Chen R, Jabri A, et al. Clinical characteristics of Covid-19 in New York city. N Engl J Med 2020;382:2372-4

35. Guan WJ, Ni ZY, Hu Y, Liang WH, Ou CQ, He JX, et al. Clinical characteristics of coronavirus disease 2019 in China. N Engl J Med 2020;382:1708-20.

36. Cheung KS, Hung IF, Chan PP, Lung KC, Tso E, Liu R, et al. Gastrointestinal manifestations of SARS-CoV-2 infection and virus load in fecal samples from the Hong Kong cohort and systematic review and meta-analysis. Gastroenterology 2020;159:81-95.

37. Yuki K, Fujiogi M, Koutsogiannaki S. COVID-19 pathophysiology: A review. Clin Immunol 2020;215:108427.

38. Young BE, Ong SW, Kalimuddin S, Low JG, Tan SY, Loh J, et al. Epidemiologic features and clinical course of patients infected with SARS-CoV-2 in Singapore. JAMA 2020;323:1488-94.

39. People with Certain Medical Conditions. Available from: https://www. cdc.gov/coronavirus/2019-ncov/need-extra-precautions/people-withmedical-conditions.html. [Last accessed on 2020 Oct 01]

40. Barnkob MB, Pottegard A, Støvring H, Haunstrup TM, Homburg K, Larsen $\mathrm{R}$, et al. Reduced prevalence of SARS-CoV-2 infection in $\mathrm{ABO}$ blood group O. Blood Adv 2020;4:4990-3

41. WangW, Xu Y, Gao R, Lu R, Han K, Wu G, et al. Detection of SARSCoV-2 in different types of clinical specimens. JAMA 2020;323: 1843-4.

42. Li G, Lili R, Siyuan Y, Meng X, De C, Fan Y, et al. Profiling early humoral response to diagnose novel coronavirus disease (COVID-19) Clin Infect Dis 2020;71:778-85

43. Bond K, Nicholson MS, Hoang MT, Catton M, Howden B, Williamson D, et al. Evaluation of serological tests for SARS-CoV-2: Implications for serology testing in a low-prevalence setting. J Infect Dis 2020;222:1280-8

44. Rodriguez-Morales AJ, Cardona-Ospina JA, Gutiérrez-Ocampo E, Villamizar-Peña R, Holguin-Rivera Y, Escalera-Antezana JP, et al. Clinical, laboratory and imaging features of COVID-19: A systematic review and meta-analysis. Travel Med Infect Dis 2020;34:101623.

45. Shi H, Han X, Jiang N, Cao Y, Alwalid O, Gu J, et al. Radiological findings from 81 patients with COVID-19 pneumonia in Wuhan, China: A descriptive study. Lancet Infect Dis 2020;20:425-34.

46. Mao R, Qiu Y, He JS, Tan JY, Li XH, Liang J, et al. Manifestations and prognosis of gastrointestinal and liver involvement in patients with COVID-19: A systematic review and meta-analysis. Lancet Gastroenterol Hepatol 2020;5:667-78.

47. Long B, Brady WJ, Koyfman A, Gottlieb M. Cardiovascular complications in COVID-19 Am J Emerg Med 2020;38:1504-7.

48. Mao L, Jin $\mathrm{H}$, Wang $\mathrm{M}, \mathrm{Hu} \mathrm{Y}$, Chen S, He Q, et al. Neurologic manifestations of hospitalized patients with coronavirus disease 2019 in Wuhan, China. JAMA Neurol 2020;77:1-9.
49. Clinical Management Protocol: COVID-19. Available from: https:// www.mohfw.gov.in/pdf/ClinicalManagementProtocolforCOVID-19. pdf. [Last accessed on 2020 Sep 29].

50. Wu CN, Xia LZ, Li KH, Ma WH, Yu DN, Qu B, et al. High-flow nasal-oxygenation-assisted fibreoptic tracheal intubation in critically ill patients with COVID-19 pneumonia: A prospective randomised controlled trial. Br J Anaesth 2020;125:e166-8.

51. Kowalewski M, Fina D, Słomka A, Raffa GM, Martucci G, Lo Coco V, et al. COVID-19 and ECMO: The interplay between coagulation and inflammation a narrative review. Crit Care 2020;24:205.

52. Bacharier LB, Guilbert TW, Mauger DT, Boehmer S, Beigelman A, Fitzpatrick AM, et al. Early administration of azithromycin and prevention of severe lower respiratory tract illnesses in preschool children with a history of such illnesses: A randomized clinical trial. JAMA 2015;314:2034-44.

53. Tchesnokov EP, Feng JY, Porter DP, Götte M. Mechanism of inhibition of Ebola virus RNA-dependent RNA polymerase by remdesivir. Viruses 2019;11:326.

54. Beigel JH, Tomashek KM, Dodd LE, Mehta AK, Zingman BS, Kalil AC, et al. Remdesivir for the treatment of Covid-19 preliminary report. N Engl J Med 2020;383:1813-26.

55. Cao B, Wang Y, Wen D, Liu W, Wang J, Fan G, et al. A trial of lopinavir-ritonavir in adults hospitalized with severe Covid-19. N Engl J Med 2020;382:1787-99.

56. World Health Organization. Repurposed Antiviral Drugs for COVID-19; Interim WHO SOLIDARITY Trial Results. Geneva: World Health Organization; 2020. Available from: https://www. medrxiv.org/content/10.1101/2020.10.15.20209817v1. [Last accessed on 2020 Oct 16].

57. FabiFlu: India's First COVID-19 Drug Launched, Priced at Rs 103 per Tablet. Available from: https://www.dnaindia.com/health/reportfabiflu-india-s-first-covid-19-drug-launched-priced-at-rs-103-pertablet-2829097. [Last accessed on 2020 Sep 29].

58. Sanders JM, Monogue ML, Jodlowski TZ, Cutrell JB. Pharmacologic treatments for coronavirus disease 2019 (COVID-19). JAMA 2020;323:1824-36

59. Alzghari SK, Acuna VS. Supportive treatment with tocilizumab for COVID-19: A systematic review. J Clin Virol 2020;127:104380.

60. Buonaguro FM, Puzanov I, Ascierto PA. Anti-IL6R role in treatment of COVID-19-related ARDS. J Transl Med 2020;18:6.

61. Gao J, Tian Z, Yang X. Breakthrough: Chloroquine phosphate has shown apparent efficacy in treatment of COVID-19 associated pneumonia in clinical studies. Biosci Trends 2020 14:72-3.

62. Yao X, Ye F, Zhang $\mathrm{M}$, Cui C, Huang $\mathrm{B}$, Niu $\mathrm{P}$, et al. In vitro antiviral activity and projection of optimized dosing design of hydroxychloroquine for the treatment of severe acute respiratory syndrome coronavirus 2 (SARS-CoV-2). Clin Infect Dis 2020;71: $732-9$

63. Mahévas M, Tran VT, Roumier M, ChabrolA, Paule R, Guillaud C, et al. Clinical efficacy of hydroxychloroquine in patients with covid-19 pneumonia who require oxygen: Observational comparative study using routine care data. BMJ 2020;369:m1844.

64. Q\&A: Hydroxychloroquine and COVID-19. Available from: https:// www.who.int/news-room/q-a-detail/q-a-hydroxychloroquine-andcovid 19?gclid=Cj0KCQjw8rT8BRCbARIsALWiOvQQWI0XvASn qP-N6dSY_NNro0sgRNazxvL0vtd-iNlFI4FavdeaeXQaAvQbEALw_ wcB\#. [Last accessed on 2020 Sep 28].

65. Huang C, Wang Y, Li X, Ren L, Zhao J, Hu Y, et al. Clinical features of patients infected with 2019 novel coronavirus in Wuhan, China. Lancet 2020;395:497-506.

66. Available from: https://www.who.int/news-room/detail/16-06-2020who-welcomes-preliminary results about-dexamethasone-use-intreating-critically-ill-COVID-19-patients. [Last accessed on 2020 Jun 22].

67. RECOVERY Collaborative Group; Horby P, Lim WS, Emberson JR, Mafham M, Bell JL, et al. Dexamethasone in hospitalized patients with Covid-19 preliminary report. N Engl J Med 2020;2020:NEJMoa2021436.

68. Sterne JA, Murthy S, Diaz JV, Slutsky AS, Villar J, Angus DC, et al. Association between administration of systemic corticosteroids and mortality among critically ill patients with COVID-19: A metaanalysis. JAMA. 2020;324:1-13.

69. Ye Z, Wang Y, Colunga-Lozano LE, Prasad M, Tangamornsuksan W, Rochwerg B, et al. Efficacy and safety of corticosteroids in COVID-19 based on evidence for COVID-19, other coronavirus infections, influenza, community-acquired pneumonia and acute respiratory distress syndrome: A systematic review and meta-analysis. Can Med 
Assoc J 2020;192:E756-67.

70. Rochwerg B, Oczkowski SJ, Siemieniuk RA, Agoritsas T, BelleyCote E, D'Aragon F, et al. Corticosteroids in sepsis: An updated systematic review and meta-analysis. Crit Care Med 2018;46:1411-20.

71. Dagens A, Sigfrid L, Cai E, Lipworth S, Cheung V, Harris E, et al. Scope, quality, and inclusivity of clinical guidelines produced early in the covid-19 pandemic: Rapid review. BMJ 2020;369:m1936.

72. Thachil J, Tang N, Gando S, Falanga A, Cattaneo M, Levi M, et al. ISTH interim guidance on recognition and management of coagulopathy in COVID-19. J Thromb Haemost 2020;18:1023-6.

73. Leng Z, Zhu R, Hou W, Feng Y, Yang Y, Han Q, et al. Transplantation of ACE2-mesenchymal stem cells improves the outcome of patients with COVID-19 pneumonia. Aging Dis 2020;11:216-28.

74. Gupta PS, Rana MK. Ivermectin, famotidine, and doxycycline: A suggested combinatorial therapeutic for the treatment of COVID-19. ACS Pharmacol Transl Sci 2020;3:1037-8.

75. Akaberi D, Krambrich J, Ling J, Luni C, Hedenstierna G, Järhult JD, et al. Mitigation of the replication of SARS-CoV-2 by nitric oxide in vitro. Redox biol 2020;37:101734

76. Kumar A, Chordia N. Bacterial resistance against antibiotics. In: Arora G, Sajid A, Kalia V, editors. Drug Resistance in Bacteria, Fungi, Malaria, and Cancer. Cham: Springer; 2017. p. 171-92.

77. Jamieson AM, Yu S, Annicelli CH, Medzhitov R. Influenza virusinduced glucocorticoids compromise innate host defense against a secondary bacterial infection. Cell Host Microbe 2010;7:103-14.

78. Zhang H, Zhang Y, Wu J, Li Y, Zhou X, Li X, et al. Risks and features of secondary infections in severe and critical ill COVID-19 patients. Emerg Microbes Infect 2020;9:1958-64

79. Schwartz IS, Friedman DZ, Zapernick L, Dingle TC, Lee N, Sligl W, et al. High rates of influenza-associated invasive pulmonary aspergillosis may not be universal: A retrospective cohort study from Alberta, Canada. Clin Infect Dis 2020;71:1760-3.

80. Binder RE, Faling LJ, Pugatch RD, Mahasaen C, Snider GL. Chronic necrotizing pulmonary aspergillosis: A discrete clinical entity. Medicine 1982;61:109-24

81. Schauwvlieghe AF, Rijnders BJ, Philips N, Verwijs R, Vanderbeke L, Van Tienen $\mathrm{C}$, et al. Invasive aspergillosis in patients admitted to the intensive care unit with severe influenza: A retrospective cohort study. Lancet Respir Med 2018;6:782-92.

82. Wang J, Yang Q, Zhang P, Sheng J, Zhou J, Qu T. Clinical characteristics of invasive pulmonary aspergillosis in patients with COVID-19 in Zhejiang, China: A retrospective case series. Crit Care 2020;24:1-4

83. Chindamporn A, Chakrabarti A, Li R, Sun PL, Tan BH, Chua M, et al. Survey of laboratory practices for diagnosis of fungal infection in seven Asian countries: An Asia Fungal Working Group (AFWG) initiative. Med Mycol 2017;56:416-25.

84. Koehler P, Cornely OA, Böttiger BW, Dusse F, Eichenauer DA, Fuchs F, et al. COVID-19 associated pulmonary aspergillosis. Mycoses 2020;63:528-34

85. Arkel AL, Rijpstra TA, Belderbos HN, van Wijngaarden P, Verweij PE, BentvelsenRG. COVID-19 Associated pulmonary aspergillosis. Am J Respir Crit Care Med 2020;202:132-5

86. Russell CD, Millar JE, Baillie JK. Clinical evidence does not support corticosteroid treatment for $2019-\mathrm{nCoV}$ lung injury. Lancet 2020;395:473-5.

87. Hotez PJ. Linking tropical infections to hypertension: New comorbid disease paradigms in our era of "blue marble health". J Am Heart Assoc 2019;8:e03984

88. Spagnolo P, Balestro E, Aliberti S, Cocconcelli E, Biondini D, Casa GD, et al. Pulmonary fibrosis secondary to COVID-19: A call to arms? Lancet Respir Med 2020;8:750-2.

89. Van De Veerdonk FL, Gresnigt MS, Romani L, Netea MG, Latge JP. Aspergillus fumigatus morphology and dynamic host interactions. Nat Rev Microbiol 2017;15:661-74.

90. Tolle LB, Standiford TJ. Danger-associated molecular patterns (DAMPs) in acute lung injury. J Pathol 2013;229:145-56

91. Cunha C, Carvalho A, Esposito A, Bistoni F, Romani L. DAMP signaling in fungal infections and diseases. Front Immunol 2012;3:286.

92. Sorci G, Giovannini G, Riuzzi F, Bonifazi P, Zelante T, Zagarella S, et al. The danger signal S100B integrates pathogen-and danger-sensing pathways to restrain inflammation. PLoS Pathog 2011;7:e1001315.

93. Borger P, Koëter GH, Timmerman JA, Vellenga E, Tomee JF, Kauffman HF. Proteases from Aspergillus fumigatus induce interleukin (IL)-6 and IL-8 producin in airway epithelial cell lines by transcriptional mechanisms. J Infect Dis 1999;180:1267-74.

94. Netea MG, Giamarellos-Bourboulis EJ, Domínguez-Andrés J, Curtis N, van Crevel R, van de Veerdonk FL, et al. Trained immunity:
A tool for reducing susceptibility to and the severity of SARS-CoV-2 infection. Cell 2020;181:969-77.

95. Arastehfar A, Wickes BL, Ilkit M, Pincus DH, Daneshnia F, Pan W, et al. Identification of mycoses in developing countries. J Fungi 2019;5:90.

96. Rutsaert L, Steinfort N, Van Hunsel T, Bomans P, Naesens R, Mertes H, et al. COVID-19-associated invasive pulmonary aspergillosis. Ann. Intensive Care 2020;10:1-4.

97. Wahidi MM, Lamb C, Murgu S, Musani A, Shojaee S, Sachdeva A, et al. American Association for Bronchology and Interventional Pulmonology (AABIP) statement on the use of bronchoscopy and respiratory specimen collection in patients with suspected or confirmed COVID-19 infection. J Bronchology Interv Pulmonol 2020;27:e52-4.

98. Ullmann AJ, Aguado JM, Arikan-Akdagli S, Denning DW, Groll AH, Lagrou $\mathrm{K}$, et al. Diagnosis and management of Aspergillus diseases: Executive summary of the 2017 ESCMID-ECMM-ERS guideline. Clin Microbiol Infect 2018;24:e1-38.

99. Baniasadi S, Farzanegan B, Alehashem M. Important drug classes associated with potential drug-drug interactions in critically ill patients: Highlights for cardiothoracic intensivists. Ann Intens Care 2015;5:44.

100. Patterson TF, Thompson GR $3^{\text {rd }}$, Denning DW, Fishman JA, Hadley S, Herbrecht R, et al. Practice guidelines for the diagnosis and management of aspergillosis: 2016 update by the infectious diseases society of America. Clin Infect Dis 2016;63:e1-60.

101. Jenks JD, Salzer HJ, Prattes J, Krause R, Buchheidt D, Hoenigl M. Spotlight on isavuconazole in the treatment of invasive aspergillosis and mucormycosis: Design, development, and place in therapy. Drug Des Dev Ther 2018;12:1033-44.

102. Puelles VG, Lütgehetmann M, Lindenmeyer MT, Sperhake JP, Wong MN, Allweiss L, et al. Multiorgan and renal tropism of SARSCoV-2. N Engl J Med 2020;383:590-2.

103. Takano T, Akiyama M, Doki T, Hohdatsu T. Antiviral activity of itraconazole against type I feline coronavirus infection. Vet Res 2019;50:5.

104. Nield B, Larsen SR, van Hal SJ. Clinical experience with new formulation SUBA $®$-itraconazole for prophylaxis in patients undergoing stem cell transplantation or treatment for haematological malignancies. J Antimicrob Chemother 2019;74:3049-55

105. Wiederhold NP, Locke JB, Daruwala P, Bartizal K. Rezafungin (CD101) demonstrates potent in vitro activity against Aspergillus, including azole-resistant Aspergillus fumigatus isolates and cryptic species. J Antimicrob Chemother 2018;73:3063-7.

106. Dias LD, Blanco KC, Bagnato VS. COVID-19: Beyond the virus. The use of photodynamic therapy for the treatment of infections in the respiratory tract. Photodiagnosis Photodyn Ther 2020;31:101804.

107. World Health Organization. Consideration in the Investigation of Cases and Clusters of COVID-19: Intern Guidance. Geneva: World Health Organization; 2020. https://www.apps.who.int/iris/ handle/10665/331668.License:CCBY-NC-SA3.0IGOYu. [Last accessed on 2020 Apr 02]

108. Yu P, Zhu J, Zhang Z, Han Y. A familial cluster of infection associated with the 2019 novel coronavirus indicating possible person-to-person transmission during the incubation period. J Infect Dis 2020;221: 1757-61.

109. World Health Organization. Advice on the Use of Masks in the Context of COVID-19: Interim Guidance. Geneva: World Health Organization; 2020. Available from: https://www.apps.who.int/iris/ handle/10665/332293. [Last accessed on 2020 Jun 05].

110. Interim Infection Prevention and Control Recommendations for Healthcare Personnel during the Coronavirus Disease 2019 (COVID-19) Pandemic; 2020. Available from: https://www.cdc.gov/ coronavirus/2019-ncov/hcp/infection-control-recommendations. [Last accessed on 2020 Oct 01]

111. Social Stigma associated with COVID-19. Available from: https:// www.who.int/docs/default-source/coronaviruse/covid19-stigmaguide.pdf.

112. Shen C, Wang Z, Zhao F, Yang Y, Li J, Yuan J, et al. Treatment of 5 critically ill patients with COVID-19 with convalescent plasma. JAMA 2020;323:1582-9.

113. Long QX, Tang XJ, Shi QL, Li Q, Deng HJ, Yuan J, et al. Clinical and immunological assessment of asymptomatic SARS-CoV-2 infections. Nat Med 2020;26:1200-4

114. Robbiani DF, Gaebler C, Muecksch F, Lorenzi JC, Wang Z, Cho A, et al. Convergent antibody responses to SARS-CoV-2 infection in convalescent individuals. bioRxiv 2020;584:437-42.

115. Zhu FC, Li YH, Guan XH, Hou LH, Wang WJ, Li JX, et al. Safety, tolerability, and immunogenicity of a recombinant adenovirus Type- 
5 vectored COVID-19 vaccine: A dose-escalation, open-label, nonrandomised, first-in-human trial. Lancet 2020;395:1845-54.

116. Grifoni A, Weiskopf D, Ramirez SI, Mateus J, Dan JM, Moderbacher CR, et al. Targets of T cell responses to SARS-CoV-2 coronavirus in humans with COVID-19 disease and unexposed individuals. Cell 2020;181:1489-501.e15.

117. To KK, Hung IF, Ip JD, Chu AW, Chan WM, Tam AR, et al. COVID-19 re-infection by a phylogenetically distinct SARS-coronavirus-2 strain confirmed by whole genome sequencing. Clin Infect Dis 2020;2020:ciaa1275.

118. Findings from Investigation and Analysis of re-positive Cases. Available from: https://www.cdc.go.kr/board/board. es? $\mathrm{mid}=\& \mathrm{bid}=0030 \&$ act $=$ view\&list_no $=367267 \&$ nPage $=1$. [Last accessed on 2020 Oct 01]

119. Iwasaki A. What reinfections mean for COVID-19. Lancet Infect Dis $2020 ; 2020: 30783$ 